\title{
Esophageal Leiomyoma as Unexpected Finding during Laparoscopic Hiatal Hernia Repair
}

\author{
Ivanov $\mathrm{K}^{1 *}$, Ignatov $\mathbf{V}^{1}$, Shterev $\mathrm{S}^{1}$, Zlatarov $\mathbf{A}^{1}$, Tonev $\mathbf{A}^{1}$, Petrov $\mathrm{D}^{1}$, Naydenova $\mathrm{B}^{2}$ and Kolev $\mathrm{N}^{1}$ \\ ${ }^{1}$ Department of General and Operative Surgery, Medical University of Varna, Bulgaria \\ ${ }^{2}$ Department of Anesthesiology, Medical University of Varna, Bulgaria
}

Submission: September 09, 2017; Published: November 16, 2017

"Corresponding author: Ivanov K, Department of General and Operative Surgery, Medical University of Varna, 55 Main Drinov Street, Bulgaria, Email: kdi@abv.bg

\begin{abstract}
Leiomyoma is the most common benign esophageal tumour. Although hiatal hernia is another common esophageal disease its association with leiomyoma is very rare. A case of leiomyoma in the lower third of the esophagus missed during preoperative diagnosis and revealed intraoperatively during simultaneous laparoscopic surgery for hiatal hernia and chronic calculus cholecystitis was reported.
\end{abstract}

\section{Introduction}

Leiomyoma is the most common benign esophageal tumour. Although hiatal hernia is another common esophageal disease its association with leiomyoma is very rare [1-4]. We report a case of simultaneous laparoscopic surgery for hiatal hernia and chronic calculus cholecystitis during which intramural leiomyoma has been detected in the lower third of the esophagus. Esophagogastric resection and cholecystectomy were performed.

\section{Case Report}

We report a case of 70-year-old woman which presents with complains of pain in the upper right quadrant and epigastrium, heartburn, nausea and constipation. Laboratory results are normal. Esophagogastroscopy reveals a hiatal hernia and reflux esophagitis confirmed by computer tomography along with calculus cholecystitis (Figure 1). Elective laparoscopic hiatal hernia repair and cholecystectomy is planned. Laparoscopy detects hiatus of $3 \times 4 \mathrm{~cm}$ and axial hiatal hernia of $39 \times 43 \times 45 \mathrm{~mm}$ fixed in the lower mediastinum, further mediastinal dissection revealed a tumour (Figure 2). Intraoperative endoscopic ultrasound confirms the presence of intramural round tumour with well-defined borders originating from the muscle layer. After upper median laparotomy, we perform a resection of the distal esophagus and the gastric cardia followed by termino-lateral esophagogastric anastomosis with circular stapler, intrathoracic fundoplication above the anastomosis as well as crural repair. Nutritional jejunostomy is placed. Enteral feeding starts on the $24^{\text {th }}$ postoperative hour, oral intake for liquids is restored after the $48^{\text {th }}$ hour and solid foods are allowed after the $72^{\text {nd }}$ hour. The postoperative course is uneventful and the patient is discharged on the $5^{\text {th }}$ postoperative day.
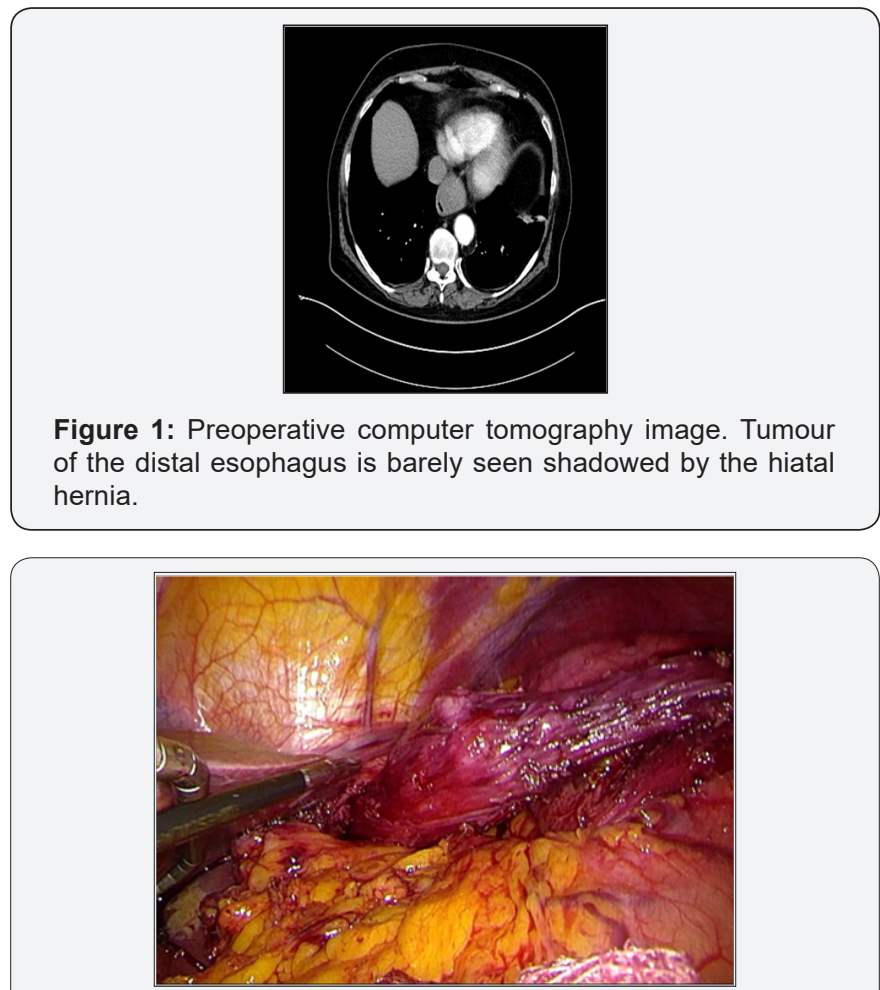

Figure 2: Intraoperative view on the mobilized esophagus. The tumor is localized $1 \mathrm{~cm}$ above the gastric cardia. 


\section{Discussion}

Leiomyomas remain asymptomatic in $50 \%$ of the patients, while the most common symptom is dysphagia combined with chest pain, pyrosis and retrosternal discomfort [5]. Esophageal leiomyoma could be expected to occur from time to time in association with hiatal hernia, the most common lower oesophageal lesion [2]. This author describes two rare cases of hiatal hernia and leiomyoma of the esophagus that remain undetected during preoperative studies. A patient with unexpected intraoperative diagnosis of a large distal esophageal leiomyoma found during laparoscopic repair of a type III hiatal hernia complicated by Cameron ulcer and chronic anemia is also reported [6]. The largest series of leiomyoma in combination with associated esophageal disorders, including hiatal hernia, epiphrenic diverticulum and achalasia is published [4]. Tumour enucleation is successfully performed in 63 patients, esophageal resection in three, and videothoracoscopic enucleation in six ones. Unfortunately, small leiomyomas with intramural growth could be easily missed on esophagoscopy and barium study [2].

\section{Conclusion}

Diagnosing the frequent esophageal pathology such as hiatal hernia should not overshadow other rare findings such as benign esophageal tumours. During the laparoscopic hiatal hernia repair, the surgeon should be cautious for other disorders that may change the course of surgery. Esophageal leiomyoma management is well-studied and several minimally invasive options are available, however, the primary cause of surgery should not be ignored.

\section{References}

1. Beek FA (1957) [A patient with a hiatal hernia, a diverticulum \& a leiomyoma of the esophagus]. Belg Tijdschr Geneesk 13(24): 12201222.

2. Borrie J (1960) Unsuspected oesophageal leiomyoma found at hiatal herniorrhaphy. Br Med J 1(5178): 1018-1020.

3. Cherniavskiı AA, Teplova GS (1987) Combined angioleiomyoma of the esophagus with duodenal ulcer and hiatal hernia. Vestn Khir Im I I Grek 139(11): 77-79.

4. Bonavina L, Segalin A, Rosati R, Pavanello M, Peracchia A (1995) Surgical therapy of esophageal leiomyoma. J Am Coll Surg 181(3): 257262.

5. Pinheiro FA, Campos AB, Matos JR, Araripe DP (2013) Videoendoscopic surgery for the treatment of esophagus' leiomyoma. Arq Bras Cir Dig 26(3): 234-237.

6. Holzinger F, Giachino D, Diamantis KE, Birrer S (2007) Unerwarteter, intraoperativer Befund im Bereiche des distalen Ösophagus. Der Chirurg 78(6): 548-551.

This work is licensed under Creative Commons Attribution 4.0 License DOI: 10.19080/ARGH.2017.07.555718

\section{Your next submission with Juniper Publishers will reach you the below assets}

- Quality Editorial service

- Swift Peer Review

- Reprints availability

- E-prints Service

- Manuscript Podcast for convenient understanding

- Global attainment for your research

- Manuscript accessibility in different formats

( Pdf, E-pub, Full Text, Audio)

- Unceasing customer service

Track the below URL for one-step submission https://juniperpublishers.com/online-submission.php 